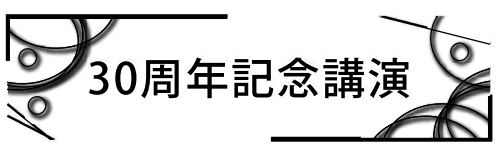

\title{
固気二相流の離散粒子シミュレーションの進展*
}

\section{Development of Discrete Particle Simulation of \\ Gas-Solid Two-Phase Flow}

\author{
田中 敏 嗣** \\ TANAKA Toshitsugu
}

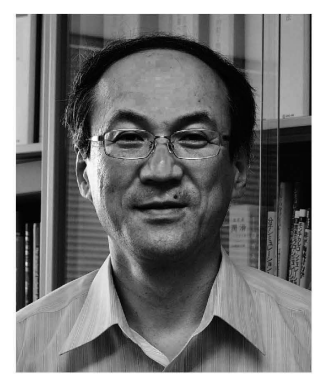

\begin{abstract}
The development of numerical simulation models and methods in gas-solid two-phase flows by the author's group in the last three decades is briefly reviewed. Eulerian-Lagrangian coupling simulations have been largely developed, especially DEM-CFD coupling simulation has become popular, and widely used in many operations of powder technology field. The establishment of the Japan society for multiphase flow played a very important role in the development of DEM-CFD coupling model.
\end{abstract}

Keywords: Gas-solid flow, DEM-CFD coupling model, Pipe flow, Fluidized bed

\section{1. 緒 言}

気流中に固体粒子の浮遊した固気二相流は、流 動層、空気輸送装置、集塵や分級などの粉体プロ セス、微粉炭燃焼炉、石炭ガス化装置などの工業 装置やプロセスの他、火山爆発、火砕流、雪崩、 雲の形成など自然現象にも見られる混相流の一 分野である。また、低濃度の固気二相流は、乱流 変調の問題に関係して、液滴の分散した気液二相 流のモデルと見なされることもある。

1987 年の日本混相流学会の設立からの 30 年の 間に、 Lagrange 型の粒子追跡法と Euler 型の数值 流体力学（CFD）をカップリングする Euler-Lagrange 法による数值解析モデルと手法が 大きく進展した。ここでは、とくに特徴的な粒子 の扱いに着目し、粒子相単独の扱いを含めて離散 粒子シミュレーションと呼ぶことにする。日本混 相流学会の設立当時は離散粒子シミュレーショ ンの黎明期であり、今から考えると、そこには開 拓すべき原野が拡がっていた。

日本混相流学会の設立は、その後の筆者らのグ ループによる高濃度固気二相流のモデリングの 進展に大きな役割を果たした。離散粒子シミュレ ーション全般の発展については、日本混相流学会 の設立 25 周年の際の著者による解説[1]があるの
で、ここでは筆者らによる高濃度固気二相流のモ デリングの進展への取組に焦点を当てて述べる ことにする。

\section{2. 混相流学会設立時の状況}

まず、混相流学会設立（1987 年）前後の希薄 系および高度系における固気二相流数值解析技 術に関する状況について振り返ってみる。

\section{1 希薄系}

希薄系固気二相流の Two-way カップリングに よる Euler-Lagrange シミュレーションは Crowe ら [2]による Particle-Source-In Cell (PSI Cell) モデル から始まる (1977 年)。PSI Cell モデルは、粒子・ 流体間の運動量の交換を、その粒子の含まれる流 体計算セルと対応付けるモデルであり、これによ り両相間の相互作用を考慮した Two-way の計算 が可能となる。国内においては、流路内固気二相 流を対象として、辻らにより粒子追跡型シミュレ ーションが行われていた[3,4]。辻ら[4]は、水平チ ヤネル内の流れに対して、粒子の浮遊を維持する ための不規則反発モデルを提案していた（1987）。

\section{2 高濃度系}

混相流学会設立当時、以後の濃厚系固気二相流 の離散粒子シミュレーションの発展を駆動する

* 2017.9.15 受付

** 大阪大学大学院工学研究科 干565-0871 吹田市山田丘 2-1

TEL: (06)6879-7316 FAX: (06)6879-7316 E-mail: tanaka@mech.eng.osaka-u.ac.jp 
二つの分野における発展があった。そのひとつは、 1979 年に地盤工学の分野において Cundall と Strack により提案された離散要素法 (Discrete Element Method、以後、DEM）[5]であり、もうひ とつは、流動層の分野における二流体モデルの発 展である。

Cundall と Strack は、地盤を構成する岩石間の 接触による相互作用力を、ばね、ダッシュポット、 摩擦スライダを用いて表される接触力モデルに より与え、197 個の岩石群の力学的挙動を数值解 析により求めた。これにより、粒状体群の堆積層 の静力学から、雪崩のような濃厚な粒状体群の動 力学を扱うことが可能となった。当初、本手法は 地盤工学の分野で発表されたため、地盤、土木分 野での応用が先に進み[6]、筆者がその情報を知る ことになるのは 1980 年台半ば、粉体工学の分野 においてである。

典型的な濃厚系固気二相流を取り扱う流動層 の分野において、二流体モデルのモデリングが進 んでいた。まず、Anderson と Jackson[7]により、 粒子および流体に対する質量保存則および運 動方程式に局所体積平均を施すことにより固 相および流体相に対する二流体モデルの基礎 式が導かれており（1967 年）、既に、このモデ ルに基づく数值シミュレーションにより、二次 元流動層における気泡形成まで表すことがで きることが示されていた[8,9]。二流体モデルで 高濃度固気二相流を扱う場合に問題となるのは、 固相に対する応力・ひずみ関係を与える構成式の モデル化である。当時、Gidaspow らのグループ では、粉粒体の Kinetic theory に基づくモデルに よる展開が行われていた[9]。

\section{DEM-CFD モデリングの発展}

混相流学会設立当時（1987 年）、筆者の所属 した研究室では空気輸送の研究が行われており、 輸送方式として主流になりつつあった低速高濃 度輸送（プラグ輸送）の実験を、辻裕先生が進め られていた。プラグ輸送では、粒子群は輸送管を 栓（プラグ）状に塞いだ状態で輸送されるため、 それまでの流体中での粒子運動と管壁での衝突 からなる希薄系の離散粒子シミュレーション手 法の適用は不可能であった。そのような状況の中、 粉体工学分野を通じて辻裕先生により DEM の情 報が持ち込まれ、これを用いて水平管プラグ輸送
の計算を行うこととなり、修士研究のテーマに設 定して私が指導を担当することになった。

筆者はそれまで管内固気二相流の計測を行 っており、数值シミュレーションの研究に関わ るのは初めてであったが、DEM で問題となる 計算の安定性などの課題はすべて解決できた。 粒子・流体間のカップリングモデルは次のよう に与えた。水平管プラグ流では、Fig. 1 に示す ように、管の下部に形成される粒子堆積層と、そ の上部の空筒流路部に分かれる。そこで、Fig. 1 に示すように管を小区間に分割し、小区間での流 体の流れる流路を粒子堆積層と上部空塔部の並 列流路と考えるモデルにより各流路の空気流量 を求めた。粒子堆積層に存在する粒子に働く流体 力は Ergunの式[10]を用いて与えた。この研究で は、周期境界をもつ水平管内で 1000 個の粒子の 運動を求め、Fig. 2 に示すように、実験で観測さ れるものと同様の流動パターンを得ることに成 功した[11,12]。

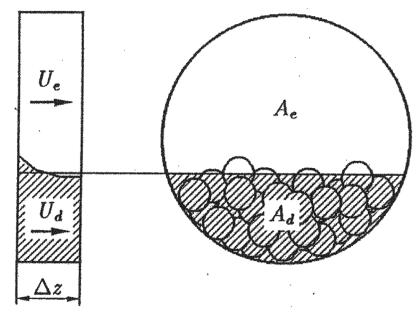

Fig. 1 Gas flow model of horizontal plug flow.

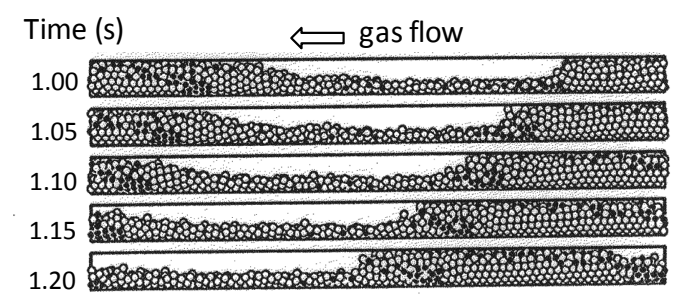

Fig. 2 Predicted flow pattern of horizontal plug flow.

混相流学会が設立されたのは、上で述べた水平 管プラグ流の DEM シミュレーションの研究を 始めた直後であった。この研究を流動層に展開 する上で混相流学会の設立は大きく役立った。筆 者は設立当初の混相流学会で企画運営委員とな り、混相流レクチャーシリーズの企画運営を担当 した。この混相流レクチャーシリーズの第 2 回が 1988 年 12 月に開催され、そのテーマは「固気二 
相流の数値シミュレーション」であった。ここで、 東京農工大学の堀尾正勒先生による「流動層のシ ミュレーション」の講義があり、2.2 節で述べた この分野の状況を知ることができた。このことは、 筆者らの研究を流動層分野に拡げる上で非常に 大きな役割を果たした。

このような経緯の下、翌年（1989 年）4 月か らの修士研究テーマとして、鉛直管内プラグ流で はなく流動層のシミュレーションが設定された。 局所体積平均化された流体流れに関する基礎式 と固相との間のカップリングモデルについては 二流体モデルの情報を利用することができた。 流体計算は、有限体積法に基づき SIMPLE 法を 用いる手法[13]により行い、粒子・流体間のカ ップリングは PSI Cell の考え方を踏襲した。ま た、水平管プラグ流では接触力モデルに非線形 な Hertz-Mindlin モデル[14,15]に粒子のヤング 率を適用するモデルを用いたが、流動の接触力 モデル依存性が小さいことから、計算負荷を軽 減するために接触力モデル中のばね定数を大 幅に小さくした線形モデルを用いた。その結果、 2400 個の粒子を用いて流動層中の気泡流動化挙 動を再現することに成功し、実験とほぼ一致す る流動化挙動が得られた[16,17]。

その後の DEM-CFD シミュレーションの大き な発展は、計算機能力の向上や並列計算などの大 規模計算環境の発展によりもたらされた。DEM により流動層中に形成される気泡を解像しよう とすると、気泡径が粒径数十個のスケールである として、2 次元の場合で $10^{4}\left(100^{2}\right)$ 個、3 次元の 場合で $10^{6}\left(100^{3}\right)$ 個程度の粒子数が必要になる。 上で述べたように、2400 個の粒子数で始められ た流動層の DEM-CFD シミュレーションは、3 次

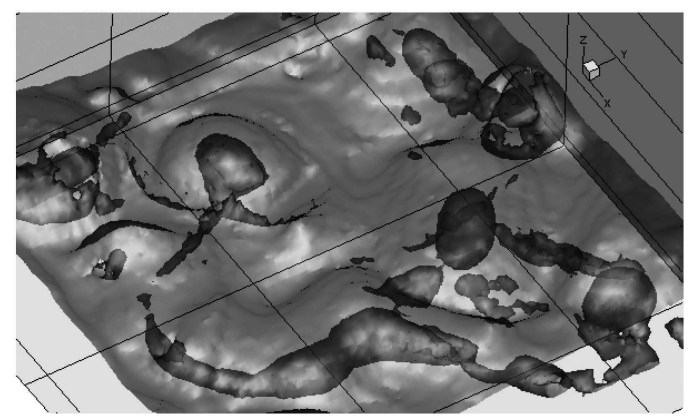

Fig. 3 Large scale structure formed in 3D fluidized bed.
元の計算に要する 100 万個のスケールを既に超 え、 1 千万個オーダー、1 億個オーダーの大規模 計算も可能となっている。3 次元の余裕を持った 計算が可能になると、3 次元の流動層中での相関 をもつ気泡を捉えることも可能となる[18]（Fig. 3)

以上のような発展の中で、取り残されていた基 本的な問題がある。それは付着力のモデリングで ある。Fig. 4 に流動層における Geldart の粒子分 類を示す[19]。Geldart の粒子分類では、流動層に おける流動化挙動の特徵により、粒子が A 粒子 から D 粒子の 4 種類に分類されている。この中 で、比較的小粒子の A 粒子と C 粒子では van der Waals 力による付着力の影響が現れ、特に C 粒子 では付着力により難流動性を示す。

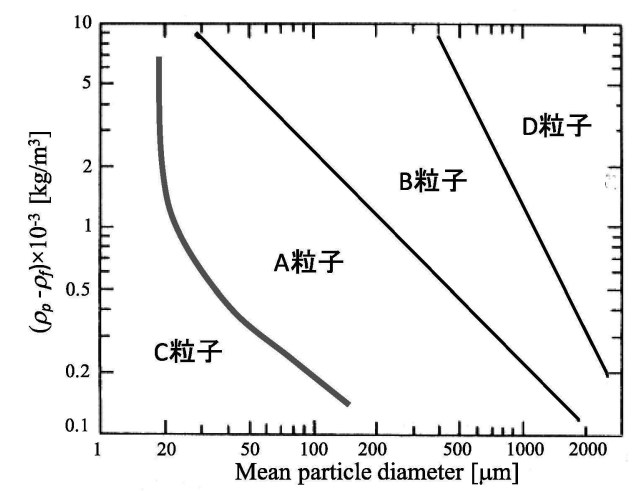

Fig. 4 Geldart map.

$\mathrm{A}$ 粒子、 $\mathrm{C}$ 粒子の流動化挙動の特長を説明する ために DEM-CFD シミュレーションによる取り 組みは行われていたが、実際に働いている付着力 に基づく定量的な検証は行われていなかった。筆 者らのグループにおいて、付着力の実測值に基づ く計算を行ったところ、実験に比べて非常に大き な付着力の影響が現れた。この原因を検討したと ころ、計算負荷軽減のために接触モデル中のばね 定数を小さく設定していることが原因であるこ とが分かった。そこで、この問題を解決するため、 単一粒子の衝突時の付着反発挙動に基づく動的 付着力モデルを提案し、計算負荷を軽減のために ばね定数を低減しながら付着力の影響を表現す ることに成功した[20]（Fig. 5)。 


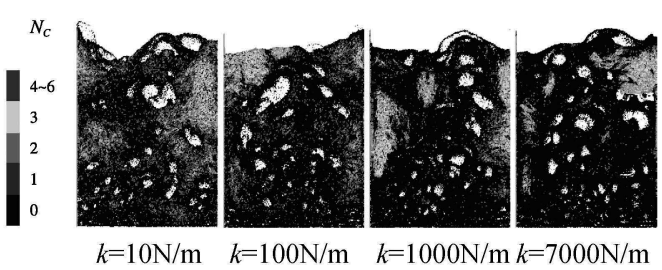

(a) with dynamic adhesion force model

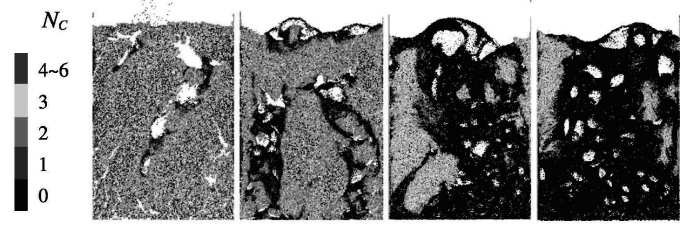

$k=10 \mathrm{~N} / \mathrm{m} \quad k=100 \mathrm{~N} / \mathrm{m} \quad k=1000 \mathrm{~N} / \mathrm{m} \quad k=7000 \mathrm{~N} / \mathrm{m}$

(b) without dynamic adhesion force model

Fig. 5 Effect of spring constant on coordination number $\left(N_{C}\right)$ distribution.

その他に、当初の DEM-CFD モデルでは流体 計算のセルサイズに比べて小さな粒径の粒子し か扱うことができなかった。この問題を解決する ために、粗大物体を微小粒子の凝集体として表す モデルを提案し、流体計算セルサイズに比べて大 きな粗大物体を含む流れの計算を可能にした[21]。

\section{6. 結 言}

以上で述べたように、日本混相流学会の設立は、 筆者らによる DEM-CFD モデルの開発と発展に 大きく寄与した。現在のように、インターネット から瞬時で広範な情報を得ることができなかっ た時代に、異なる分野の研究者を結びつけた意義 は大きい。今後も、日本混相流学会を基盤として 新たな発展が生み出されていくことに期待する。

\section{参考文献}

[1] Tanaka, T., Development of Numerical Analysis of Multiphase Flow in Powder Technology, Japanese J. of Multiphase Flow, Vol. 26(1), 392-398 (2012).

[2] Crowe, C. T., Sharma, M. P., and Stock, D. E., The Particle-Source-In Cell Model for Gas-Droplet Flows, J. of Fluids Eng., Vol. 99(2), 325-332 (1977).

[3] Morikawa, Y. and Tsuji, Y., Computer Simulation of the Pneumatic Transport of Solids in Pipes with Bends (in Japanese), Transaction of JSME, Vol. 43(375), 4158-4167 (1977).

[4] Tsuji, Y., Morikawa, Y., Tanaka, T., Nakatsukasa, N., and Nakatani, M., Numerical Simulation of Gas-Solid Two-Phase Fow in a
Two-Dimensional Horizontal Channel, Int. J. Multiphase Flow, Vol. 13(5), 671-684 (1987).

[5] Cundall, P.A. and Strack O.D.L., Discrete Numerical Model for Granular Assemblies, Geotechnique, Vol. 29, 47-65 (1979).

[6] Kiyama, H. and Fujimura, H., Application of Cundall's Discrete Block Method to Gravity Flow Analysis of Rock-Like Granular Materials, Proc. Japan Soc. Civil Engineers, Vol. 1983(333), 137-146 (1983).

[7] Anderson, T.B. and Jackson R., A Fluid Mechanical Description of Fluidized Bed, I\&EC Fundamentals, Vol. 6(4), 527-539 (1967).

[8] Pritchett, J.W., Blake, T.R., and Garg, S.K., Numerical Model of Gas Fluidized Bed, AIChE Symp. Ser., Vol. 74(176), 134-148 (1978).

[9] Bouillard, J.X., Lyczkowski, R.W., and Gidaspow, D., Porosity Distributions in a Fluidized Bed with an Immersed Obstacle, AIChE J., Vol. 35(6), 134-148 (1989).

[10] Ergun, S., Fluid Flow through Packed Columns, Chemical Engineering Progress, Vol. 48(2), 89-94 (1952).

[11] Tanaka T., Ishida, T. and Tsuji, T., Direct Numerical Simulation of Granular Plug Flow in a Horizontal Pipe (The Case of Cohesionless Particles) (in Japanese), Transaction of JSME, Vol. 57(534B), 456-463 (1991).

[12] Tsuji, T., Ishida, T. and Tanaka T.., Lagrangian Numerical Simulation of Plug Flow of Cohesionless Particles in a Horisontal Pipe, Powder Technology, Vol. 71, 239-250 (1992).

[13] Patankar, S.V., Numerical Heat Transfer and Fluid Flow, Hemisphere, (1980).

[14] Hertz, H., On the Contact of Elastic Contact, J. Reine Angew. Math., Vol. 92, 156-171 (1881).

[15] Mindlin, R.D., and Deresiewicz, H., Elastic Spheres in Contact under Varying Oblique Forces, J. Applied Mechanics, Vol. 20, 327-344 (1953).

[16] Kawaguchi, T., Tanaka, T. and Tsuji, Y., Numerical Simulation of Fluidized Bed using the Discrete Element Method (The Case of Spouting Bed) (in Japanese), Transaction of JSME Ser. B, Vol. 58(551), 2119-2125 (1992).

[17] Tsuji, Y., Kawaguchi, T. and Tanaka, T. Discrete Particle Simulation of Two-Dimensional Fluidized Bed, Powder Technology, Vol. 77, 79-87 (1993).

[18] Tsuji, T., Yabumoto K. and Tanaka T., Spontaneous Structures in Three-Dimensional Bubbling Gas-Fluidized Bed by Parallel DEM-CFD Coupling Simulation, Powder Technol., Vol. 184(2), 132-140 (2008).

[19] Geldart, D., Types of Gas Fluidization, Powder Technology, Vol. 7, 285-292 (1973). 
[20] Kobayashi, T., Tanaka, T., Shimada, N. and Kawaguchi, T., DEM-CFD Analysis of Fluidization Behavior of Geldart Group A Particles Using a Dynamic Adhesion Force Model, Powder Technology, Vol. 248, 143-152 (2013).
[21] Tsuji, T., Higashida, K., Okuyama, Y. and Tanaka T., Fictitious Particle Method: A Numerical Model for Flows Including Dense Solids with Large Size Difference, AIChE J., Vol. 60(5), 1606-1620 (2014). 